\title{
The Effectiveness of Light Shelf in Tropical Urban Context
}

\author{
Floriberta BINARTI*, Sinta DEWI \\ Architecture Department, Universitas Atma Jaya Yogyakarta, Jl. Babarsari No. 44, Kecamatan Depok, \\ Daerah Istimewa Yogyakarta 55281, Indonesia
}

\begin{abstract}
Light shelf was developed to create uniform indoor illuminance. However, in hot climates the unshaded clerestory above the shelf transmits high solar heat gain. In dense urban context, these advantages and disadvantages might vary regarding the context and position of the fenestration. This study employed an integrated energy simulation software to investigate the effectiveness of light shelf application in a tropical urban context in terms of building energy consumption. Radiance and EnergyPlus based simulations performed the effects of urban canyon aspect ratio and external surface albedo on the daylighting performances, space cooling load, as well as the lighting energy consumption of the building equipped with lightshelves in $\mathbf{2}$ humid tropical cities. Comparison of the energy performances of 3 fenestration systems, i.e. fenestration without any shading device, with overhangs, and with light shelves, yielded some recommendations concerning the best application of light shelf on the certain floor levels and aspect ratio of the urban context.
\end{abstract}

Keywords - Cooling load; daylighting performance; electrical lighting load; light shelf; urban geometry; urban surface albedo

\section{INTRODUCTION}

Light shelf is a daylight-redirecting system intended to bounce daylight to the deepest side of a room. This function suites well to all climates [1] and the performances have been studied in various climates and sky conditions. Clear sky is the favourable condition to provide high average indoor illuminance level with even distribution. A Lightscape simulation based study, which was validated by field measurements [2] proved, however, that lightshelves could improve the indoor illuminance under a partly cloudy sky in Singapore. Another study on light shelf in warm tropics has been conducted under clear sky and overcast sky conditions in Yogyakarta, Indonesia based on Radiance simulations. In case of side windows with overhang, substitution of overhang with light shelf could improve the classroom's visual uniformity [3]. To increase the effectiveness, Lim and Heng [4] employed scaled physical models and computational simulation methods to examine the daylighting performance of lightshelves under several tropical sky conditions in Subang, Malaysia, i.e., intermediate sky with direct sunlight, intermediate sky without direct sunlight and overcast sky. Under clear sky conditions, daylighting performance of light shelf depends on the dynamic movement of solar position. Franco [5] proposed tilted and automatic lightshelves to solve daylighting problems in hot tropics by adjusting the elevation of the internal shelf to the dynamic movement of solar position.

Sufficient illuminance with uniform distribution created by light shelf strongly impacts on the energy saving for lighting. An application of light shelf on an office building in warm

* Corresponding author.

E-mail address: flo.binarti@gmail.com

(C)2016 Floriberta Binarti, Sinta Dewi. This is an open access article licensed under the Creative Commons Attribution License (http://creativecommons.org/licenses/by/4.0), in the manner agreed with De Gruyter Open. 
climate of Florida saved daytime lighting energy up to $46 \%$ of the energy used for lighting in the same building with horizontal blinds [6]. In Taiwan a double layer light shelf design fitted on large windows could achieve optimum daylight illumination and reduce the lighting power cost up to $70 \%$ on the date of the winter solstice and summer solstice compared to a single shading [7]. However, the lighting energy consumed by light shelf application in hotarid climate was not lower than the energy consumed by other shading devices, such as: adaptive overhang and adaptive fins [8]. In regions with abundant solar radiation, the sunlight-exposed clerestory might cause overheating [8], [9]. Cooling load of rooms equipped with lightshelves with sunlight-exposed clerestories were much higher than the rooms equipped with shaded clerestories/windows.

Previous studies on light shelf were limited in building context. Recently, studies on urban environment have widely emerged following the awareness of the impacts on the urban climatology. Shafaghat et al. [10] established a taxonomy body of knowlege in urban climatology studies and mentioned urban street canyon, which consists of aspect ratio and street orientation, as the most important urban features. The impacts of urban height to width ratio aspect and spacing distance to length ratio on the building energy demand had been studied by Kesten et al. [11]. Additionally, canyon surfaces have been understood to be vital in determining the thermal performance of the urban canyon [10], that affected on the surrounding building energy consumption. Akbari et al. [12] found that the surrounding's surface albedo or emissivity could modify the energy balance of the buildings. High albedo materials reduce the amount of solar radiation absorbed by the building envelope. In multistorey buildings, the urban geometry and texture effects on the indoor illuminance and radiation fluxes may vary for each floor level. Therefore, it could be interesting to relate these factors to the light shelf planning in multi-storey buildings in terms of building energy performance. In order to measure the effectiveness of light shelf, the energy performance of windows equipped with light shelf was compared to that of the same windows without shading and with overhang.

\section{MethodS}

An experimental study on the effectiveness of light shelf in various urban contexs was conducted based on computational simulations performed by EnergyPlus and Radiance based softwares. These programs simulated the daylighting performance, space cooling load, and the electrical energy for artificial lighting of the building models in a tropical urban context model.

\subsection{Light Shelf Models}

Light shelf is a horizontal panel installed at a height below the clerestory and above the view window. In this study, a light shelf model was installed on an $11 \mathrm{~m}$ long classroom model that requires high daylight availability. The room models were arranged in a singlesided space layout with a $3 \mathrm{~m}$ wide corridor in a 5-storey building. This medium rise building was considered to be suitable for light shelf application and can be easily found in medium cities in tropical countries. All models had the same interior surface reflectance, i.e. 0.9 for the ceiling (concrete), 0.8 for the wall (plastered brick), and 0.5 for the floor (ceramic). The shading devices and light shelves were made of the same material (glass fibre reinforced concrete) with 0.9 for the surface reflectance.

Three room models with variation in width $(6 \mathrm{~m}, 9 \mathrm{~m}$, and $12 \mathrm{~m})$ were constructed to observe the ability of light shelf to bounce natural light into the deep side of the room. Each 
room has a different height in order to allow the daylight to penetrate into the deepest room perimeter. Clerestory head height was determined based on the daylighting rule of thumb, which prescribes 2.5 times the clerestory's head height as the maximum room width for light shelf application [13]. To prevent the occupant view from glare, an internal light shelf, which has 1.5 times the clerestory height, was mounted above occupant's eye level at the height of $2.2 \mathrm{~m}$ [14]. The internal shelf was mounted at a height below the clerestories and above the view windows. The upper surfaces of the shelves were coated with $95 \%$ reflectance aluminum film.

Other fenestration models, i.e., without shading device and with overhang, were installed on a building with the same dimension, surfaces, room arrangement and window model for comparison. The window to floor area ratio (WFR) must meet LEED requirements, i.e., $15 \%$. All windows were glazed with $6 \mathrm{~mm}$ clear glass with $19 \%$ of the maximum window to wall area ratio (WWR). The view windows had a constant area with variation in shading device (shading coefficient or SC).

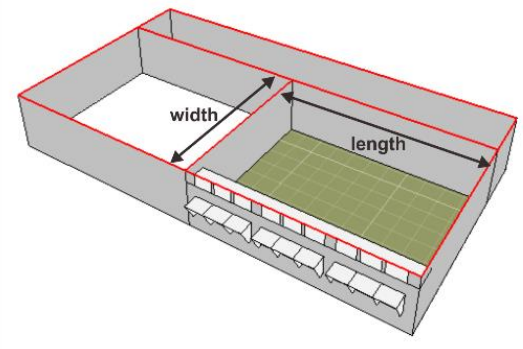

(a)

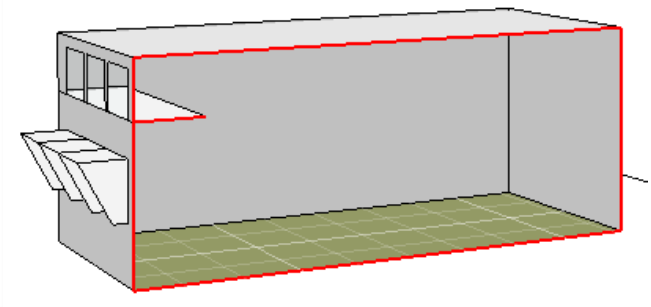

(b)

Fig. 1. (a) Room arrangement; (b) light shelf.

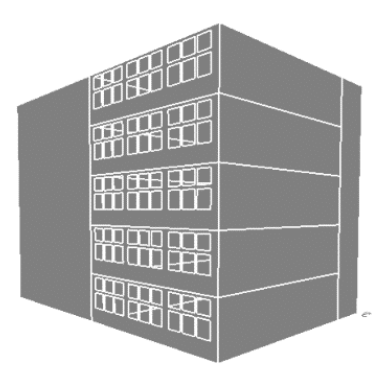

(a)

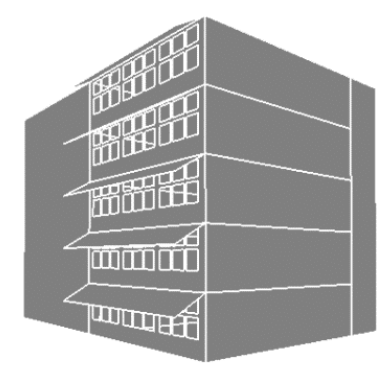

(b)

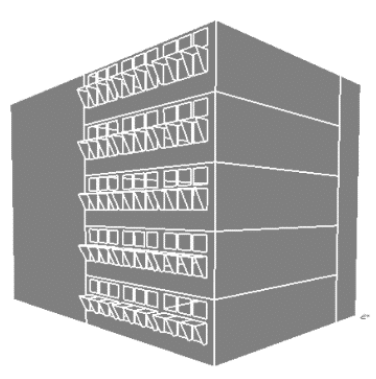

(c)

Fig. 2. Fenestration models: (a) without shading; (b) with overhang; (c) with light shelf.

\subsection{Modelling the Urban Context}

Three elements of urban context, i.e., the geometrical combination of vertical (buildings) and horizontal (streets and open areas) surfaces or aspect ratio $\left(h_{\mathrm{e}} / w_{\mathrm{e}}\right.$ or $\left.h / w\right)$, the ratio of the street/open area width to the building width $(l e / L)$, and external surface albedo, were examined. In this study, there were 2 variations in the external ground reflectance, external wall reflectance, and external 
roof reflectance. Whereas 3 variations in the $h / w$ and the $l e / L$ were $0.5,1$, and 2 ; and $0.25,0.5$, and 0.75 respectively. Variation in distances among the building model and surrounding 8 buildings having the same dimension as the building model (Fig. 3) created variation in $h / w$ and $l e / L$.

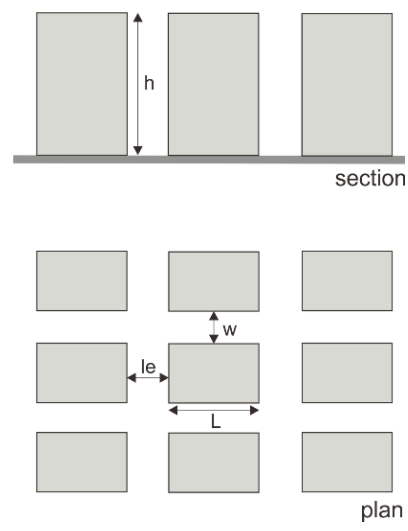

(a)

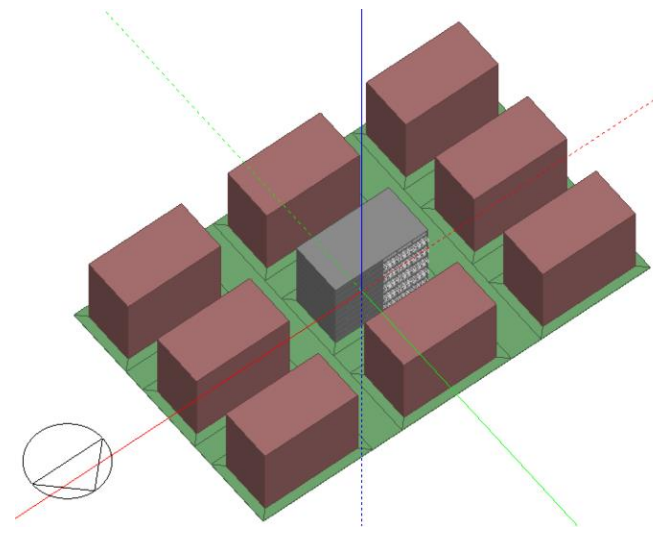

(b)

Fig. 3. (a) Urban aspect ratio or urban canyon; (b) one of the model in medium-dense urban area.

\subsection{Daylighting and Energy Simulations}

EnergyPlus [15] was employed to calculate the building cooling load and energy use for lighting. The reliability of EnergyPlus has been tested for building thermal envelope and fabric tests designated as Cases 195 through 960 of ANSI/ASHRAE Standard 140-2011 [16]. The accuracy in computing solar heat gain had been validated using test cell's monitoring data [17] and compared to other energy simulation software [18]. Several previous studies relied on EnergyPlus to perform the energy use of the building models. Hachem et al. [19] used EnergyPlus to investigate geometric form effects on solar potential of housing units in Montreal. While, Goia [20] searched the optimal window-to-wall ratio in office buildings in 4 European cities using EnergyPlus.

This study selected Adaptive Convection model to calculate the exterior and interior convective heat transfer coefficient $\left(h_{\mathrm{c} \text {,ext }}, h_{\mathrm{c}, \text { int }}\right)$. Adaptive Convection algorithm allows for finer control over the models used for particular surfaces. It classified the surfaces by flow regime and orientation. By choosing this model, the most appropriate $\mathrm{h}_{\mathrm{c}}$ equation which available in EnergyPlus would be automatically selected for a given space and at a given time during the simulation running [21].

The conduction heat flux in EnergyPlus was quantified using Conduction Transfer Function (CTF) method. CTF is an elegant and powerful solution to calculate conduction heat transfer through an element that decays rapidly when using response factor equation [15]. In EnergyPlus radiative heat transfer from urban context to the interior is determined from radiation flux exchange with the air and surroundings and the absorbed direct and diffuse solar radiation heat flux. The radiation heat flux is calculated from the surface, sky and ground temperatures, the surface absorptivity and the sky, and ground view factors. Perez solar radiation model is used to split global solar radiation into direct normal and diffuse horizontal components [21]. The transmittance of sky radiance is calculated using anisotropic radiance distribution model that has been proven as an accurate sky radiance model [18]. 
The calculation of energy use for lighting was based on the daylighting performance computed using DELight. DELight is an EnergyPlus integrated lighting software. It uses Radiosity-based algorithm to calculate the Inter Reflected Component (IRC). The integrated EnergyPlus-DELight has been tested by Carroll and Hitchcock [22] as a robust, usable and capable of providing a sufficiently accurate performance of the daylighting and lighting control system of the light redirecting system. To simulate the energy for lighting, the artificial lighting was controlled linearly over $100 \%$ area with suspended luminaires and 22 of the daylight glare index (DGI). The lamps would turn on when the average $E_{\mathrm{i}}$ was below than 300 lux.

EnergyPlus simulations were run using climatic data of Singapore (on $1^{\circ} 22^{\prime} \mathrm{N}$ ) and Yogyakarta (on $7.8^{\circ} \mathrm{S}$ ). These cities belong to the equatorial tropical region. Whole year simulation was selected to analyze the annual $D F$ and energy demand. The classroom was equipped with split air conditioner without fresh air with default coefficient of performance or COP (3.34) and supply air condition. The operation schedule of educational classroom cooling and lighting was selected in the simulation set-up.

Since the flexibility of DELight in EnergyPlus is very limited, the daylighting performance of the models in this study was analyzed using Radiance. The accuracy of Radiance, a backward raytracing based software, has been validated in some previous studies [24], [25]. Combining EnergyPlus with detailed lighting software was also implemented by Huang et al. [23] to obtain more accurate daylighting simulations. In this study, simulations under overcast sky conditions were conducted to calculate the $D F$ and the energy demand for lighting. Whereas the simulations under a clear sky with the sun were set on June 21 at 12:00, a time when the clear sky brought abundant daylight through North-facing windows for Yogyakarta and South-facing ones for Singapore. Daylighting simulations were set up in a high level of accuracy (model detail, lighting variability and image quality) with 5 indirect reflections.

\section{RESUlTS AND DiscuSSIONS}

\subsection{Daylight Factor in Highly Dense Area}

Light shelves performed the best in a wide room (6 m and $9 \mathrm{~m}$ wide rooms) compared to the daylighting performance of unshaded window or window with overhang. Fig. 4 illustrates the daylighting performance of the first floor of building models with North-facing windows located in an urban context with $h / w=4$ and $l e / L=0.25$. The applications of light shelves on wide rooms created the most uniform distribution of indoor illuminance $\left(E_{\mathrm{i}}\right)$ on the deepest perimeter. The neighbor's buildings obstructed the daylight penetration through the windows of the building model equipped with light shelves, which further decreased the $D F$ of the area near the windows. Meanwhile, the unshaded clerestories incorporating with the internal shelf transmitted and then deflected the reflected daylight from the neighbor's wall and the ground until the deepest area of the room. 


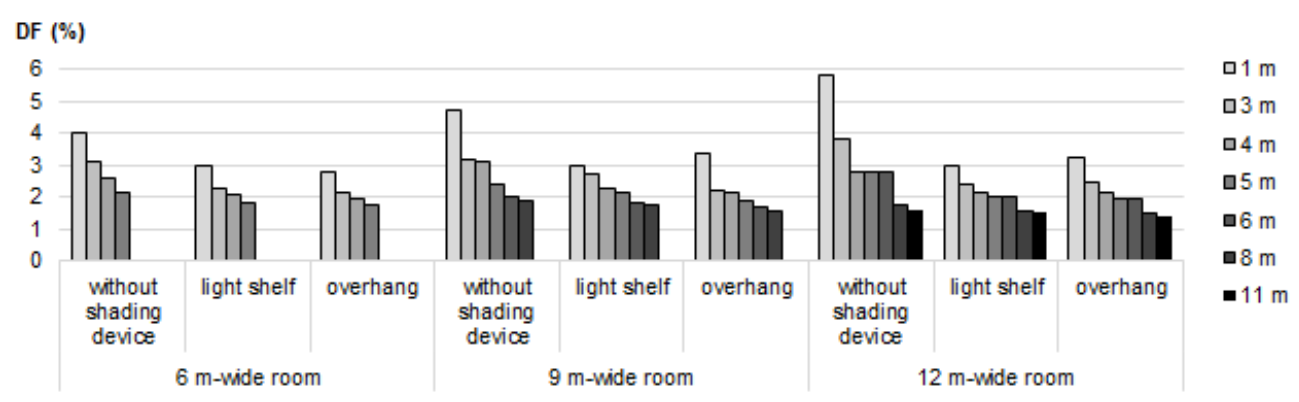

Fig. 4. $D F$ at certain distance $(\mathrm{m})$ from the windows inside $6 \mathrm{~m}, 9 \mathrm{~m}$ and $12 \mathrm{~m}$ wide rooms on the first floor in an urban area with $h / w=4$ and $l e / L=0.25$.

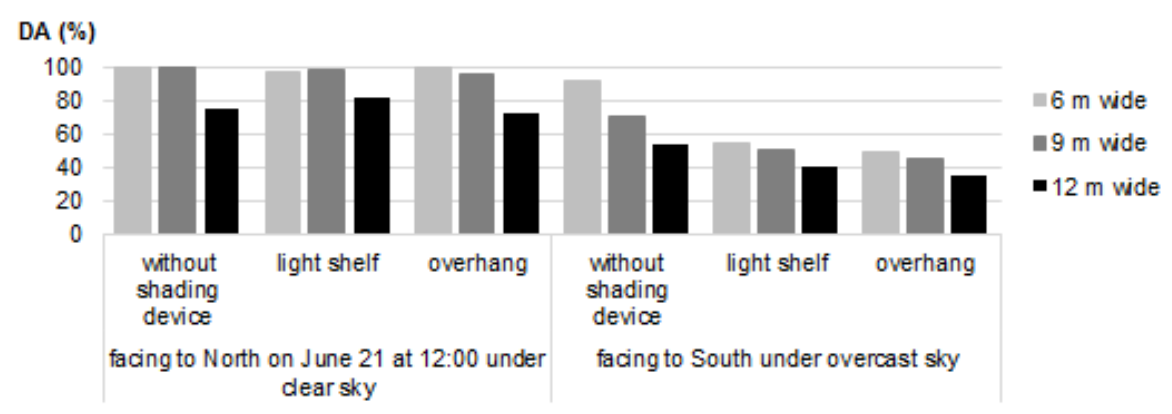

Fig. 5. Percentage of the DA of $6 \mathrm{~m}, 9 \mathrm{~m}$, and $12 \mathrm{~m}$ wide rooms with 3 variations in fenestration model on the first floor in an urban area with $h / w=4$ and $l e / L=0.25$.

Floor area percentage with $E_{\mathrm{i}}>300$ lux is another daylighting performance parameter namely Daylight Autonomy (DA). Fig. 5 displays simulation of DA for North-facing windows under peak sky luminance and for South-facing windows under an overcast sky in Yogyakarta. Compared to the DA of other fenestrations, light shelf application achieved the best DA inside a $12 \mathrm{~m}$ wide room with North-facing windows on June 21 at 12:00 under a clear sky. Light shelf became ineffective for South-facing windows under overcast sky conditions in the highly dense area in Yogyakarta, although it offered a better solution in daylighting performance than horizontal shading devices. Reflected daylight levels entering the room through the clerestory in light shelf applications could not provide sufficient average $E_{\mathrm{i}}$.

\section{2. h/w Ratio Effects on the Daylighting Performance}

Significant effects of urban aspect ratio $(h / w)$ on the $E_{\mathrm{i}}$ could be observed on the first floor of the room under clear sky conditions. $h / w$ and $l e / L$ created a balancing effect on the $E_{\mathrm{i}}$ of a room on the third floor under a clear sky. On the fifth floor under the same sky conditions, variation in $l e / L$ and $h / w$ only modified the $E_{\mathrm{i}}$ of the area near the window. However, no significant effect appeared on all floor levels in low $h / w$ due to the variation in $l e / L$. 


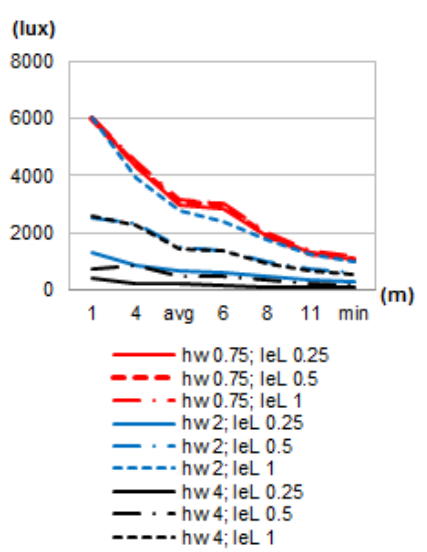

(a)

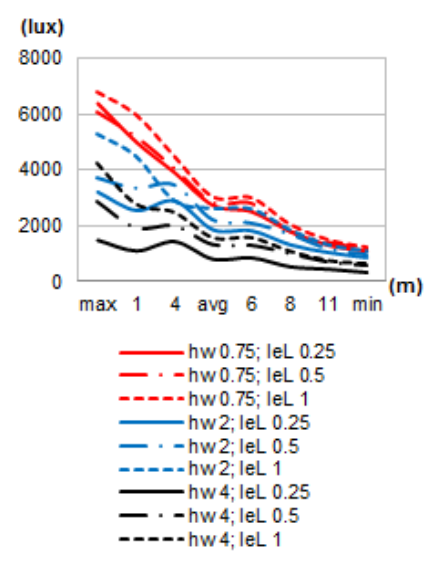

(b)

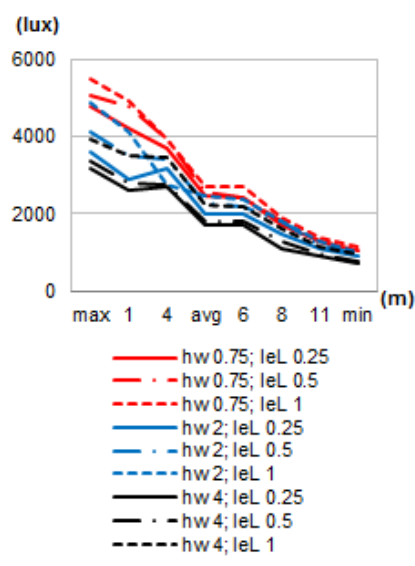

(c)

Fig. 6. $E_{\mathrm{i}}$ of a $12 \mathrm{~m}$ wide room equipped with north-oriented windows with lightshelves in Yogyakarta with varying urban geometry under clear sky on June 12 at 12 noon on the first floor (a), the third floor (b) and the fifth floor (c).

Under overcast sky conditions, the effects of $h / w$ on the $E_{\mathrm{i}}$ of the first floor were stronger than those of $l e / L$. Variation in $l e / L$ only produced significant effects on the $E_{\mathrm{i}}$ near the window in the urban area with medium or high $h / w$. Generally, it produced only small effects if the urban area had low $h / w$. On the third floor the effects of $h / w$ on the $E_{\mathrm{i}}$ of the $12 \mathrm{~m}$ wide room were more pronounce than those of $l e / L$. A similar pattern with slight effects of the urban geometry on the third floor occurred on the fifth floor.

\subsection{Albedo / Surface Reflectance Effect}
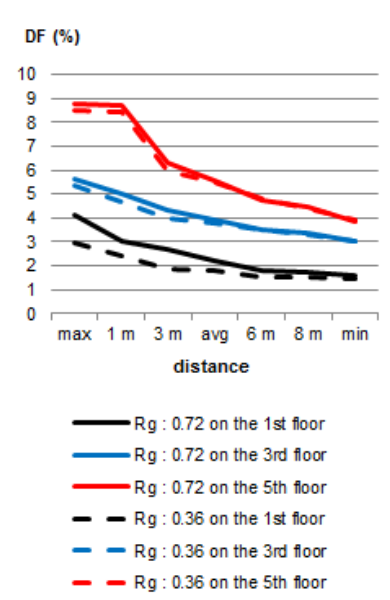

(a)
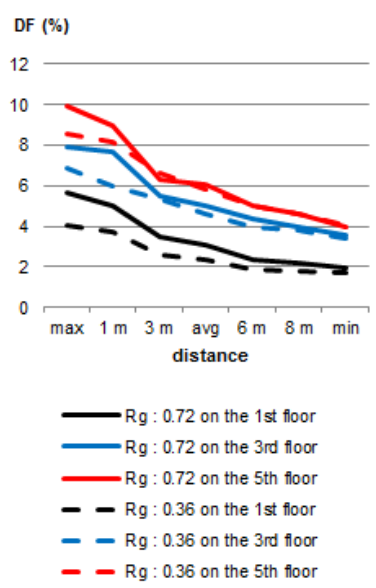

(b)
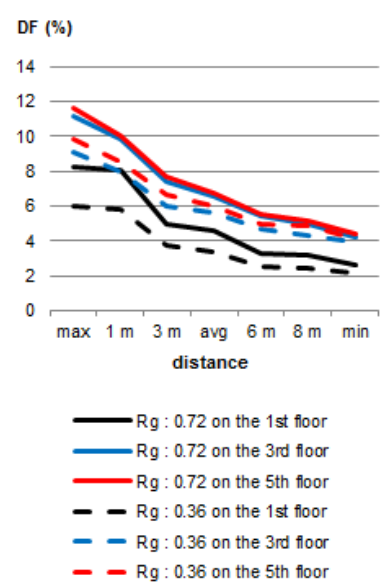

(c)

Fig. 7. $D F$ of a $12 \mathrm{~m}$ wide room equipped with North-facing windows with light shelves with 2 variations in the ground reflectance in an urban area with 3 variations in aspect ratio, i.e. $h / w=4$ and $l e / L=0.25(\mathrm{a}), h / w=2$ and $l e / L=0.25$ (b), $h / w=0.75$ and $l e / L=0.25$ (c). 
The effect of external ground reflectance on the $E_{\mathrm{i}}$ revealed on the first floor in the high-density urban area, i.e. $h / w=4$. In this urban area, diffuse natural light (especially ground reflected light) played a dominant role in providing sufficient $E_{\mathrm{i}}$ on the first floor. Substantial effect on the $D F$ appeared on the first floor room in all urban densities for south-oriented windows under overcast sky conditions. Low ground reflectance affected significantly on the $D F$. The longer the distance from the window, the lower the $D F$ would be. External wall reflectance affected the $E_{\mathrm{i}}$ and $D F$ mainly on the third and fifth level only in the high to the medium dense urban area (see Fig. 8). Significant reduction of the $D F$ due to the lower external wall reflectance occurred near the window, while a slight reduction revealed on the deepest side. Modification of the external wall reflectance only created slight effects on the $E_{\mathrm{i}}$ and $D F$ on the first floor. There was no significant reduction in the $E_{\mathrm{i}}$ and $D F$ due to the lower external roof reflectance. This is not valid for a floor level which was higher than the neighbor's roof.

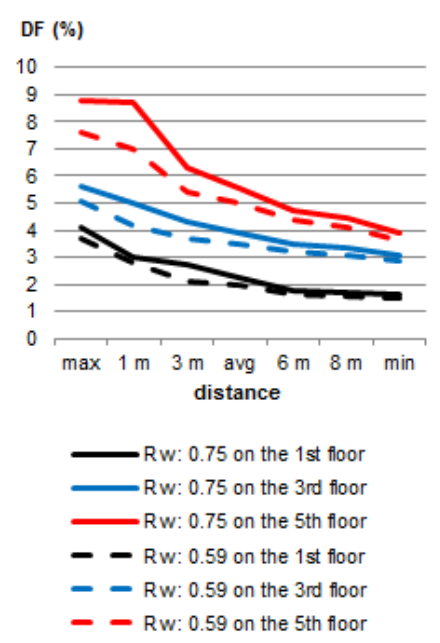

(a)

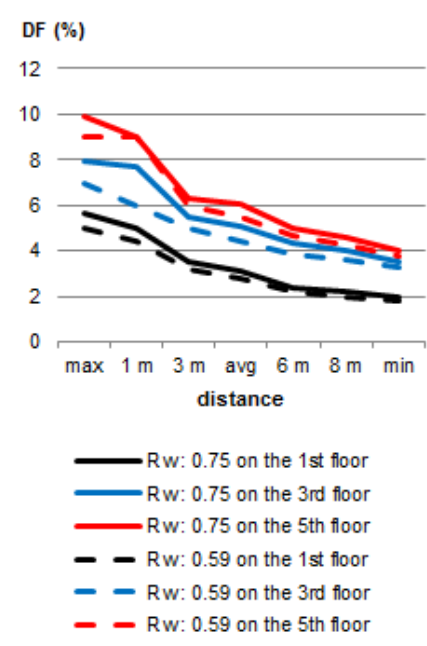

(b)

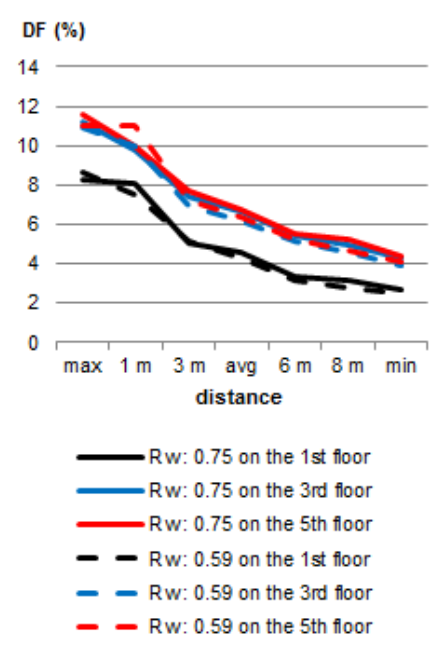

(c)

Fig. 8. $D F$ of a $12 \mathrm{~m}$ wide room equipped with North-facing windows with light shelves with 2 variations in the wall reflectance in an urban area with 3 variations in aspect ratio, i.e. $h / w=4$ and $l e / L=0.25(\mathrm{a}), h / w=2$ and $l e / L=0.25$ (b), $h / w=0.75$ and $l e / L=0.25$ (c).

External reflectance affected interestingly on the $E_{\mathrm{i}}$ of light shelf application. For the building in medium or low dense urban area, low external ground and wall reflectances potentially reduced glare without significant reduction in average $E_{\mathrm{i}}$ in the occupied zone and $E_{\mathrm{i}}$ on the deepest side of medium (to wide) rooms. High external reflectance, however, could not significantly help increasing the average $E_{\mathrm{i}}$ of the room on the first floor in highly dense urban context.

\subsection{The Space Cooling Load and Lighting Energy Consumption}

Fig. 9 and Fig. 10 indicate that light shelf can save the building energy consumption if applies in highly dense urban area (with the combination of $h / w=4$ and $l e / L=0.25$ or $h / w=2$ and $l e / L=0.25$ ) and on the first to third floor of a building. However, light shelf could perform well in low dense urban area $(h / w=0.75$ and $l e / L=0.25)$ if it was installed on the first floor. High sky luminance in humid tropics created a high external reflected component of light shelf application in the dense 
urban area, meanwhile highly dense urban area provided shading to the building facade, which further decreased the cooling load. In terms of building energy, application of light shelf on low floor levels is recommended. Fig. 9 shows that at the operational stage the energy consumption for cooling was higher than for lighting. High abundant solar radiation in the tropics demands high energy to cool the space, meanwhile the current state of lighting technology offers highly efficient lamp type, such as: Light Emitting Diode. However, fenestration application in urban context should concern the combination between energy for cooling and for lighting since the dominant contribution to the total energy consumption depends on the urban canyon aspect ratio.

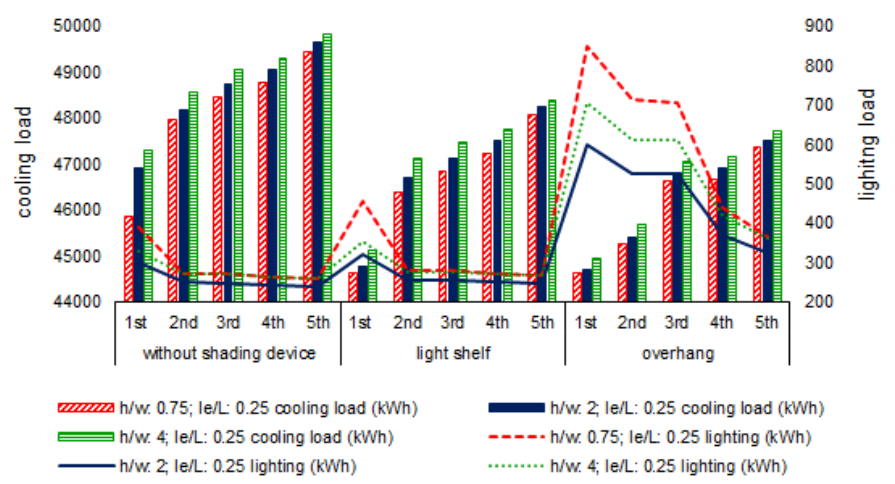

Fig. 9. One-year cooling load and energy use for lighting of fenestration models on $9 \mathrm{~m}$ wide classrooms with South-facing windows in various urban geometry in Yogyakarta.

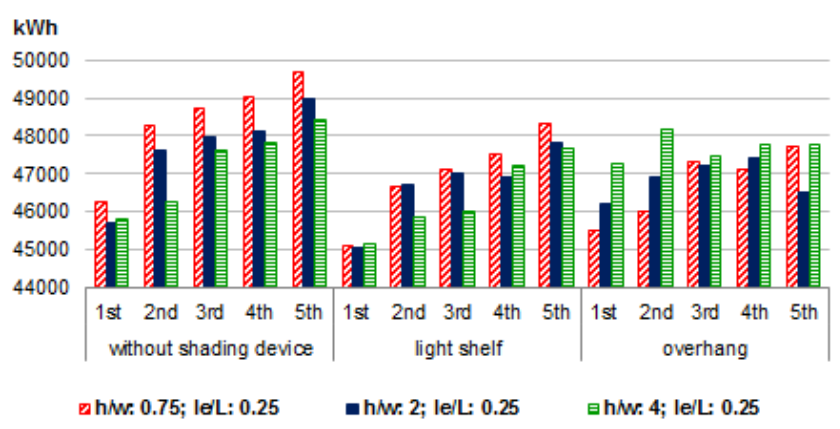

Fig. 10. One-year total cooling load and energy use for lighting of fenestration models on $9 \mathrm{~m}$ wide classrooms with Southfacing windows in various urban geometry in Yogyakarta.

Fig. 11 depicts the window orientation effects on the energy performance of each fenestration type. Aperture orientation could modify the energy consumption of space on the first and top floor of the building equipped with light shelf and without shading device. Application of light shelf on the South-facing window on the first and third floor yielded the lowest energy consumption compared to the application of other fenestrations. Application of light shelf on the top floor would consume low energy if the windows were oriented to the North or the East on the buildings in highly dense urban area in Singapore. However, EnergyPlus simulations with variation in external surface reflectance/albedo as shown by Fig. 12 demonstrated insignificant modification in the cooling load and energy for lighting. 


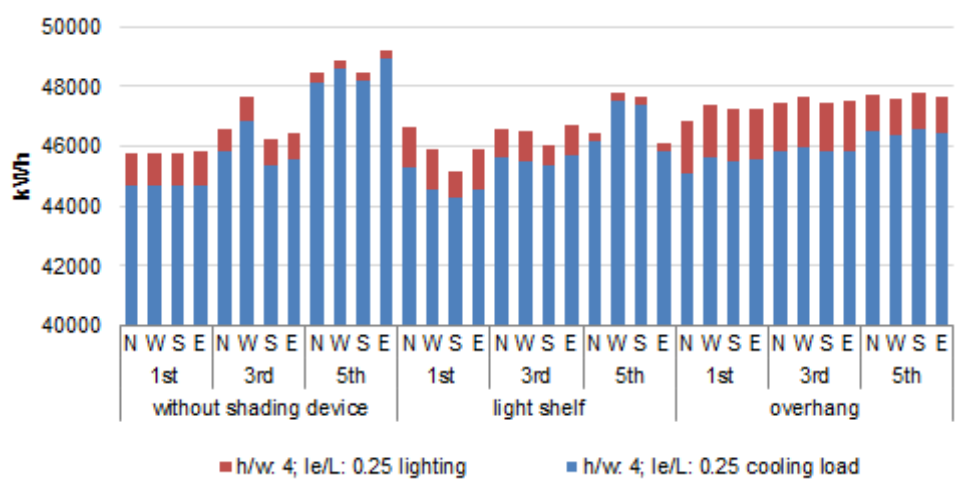

Fig. 11. A 9 m wide classrooms with various window orientations in highly dense urban area in Singapore.

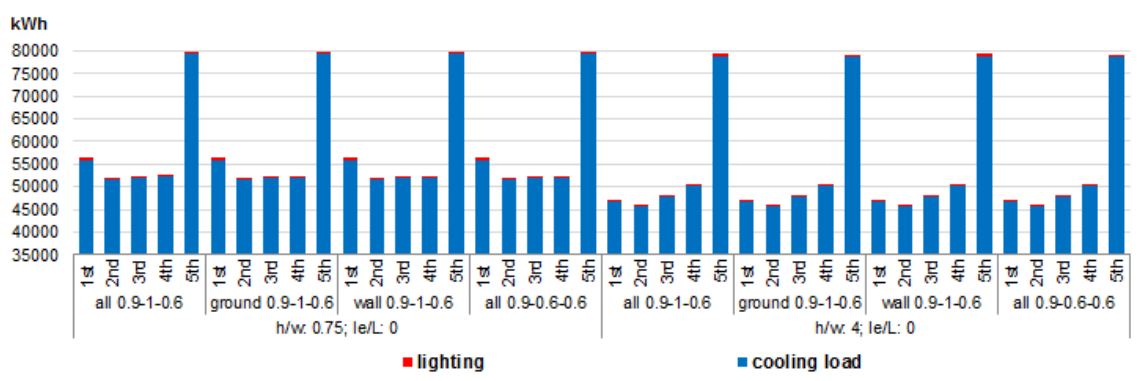

Fig. 12. One-year energy performance of fenestration models on $9 \mathrm{~m}$ wide classrooms in 2 variations of the urban geometry with 3 variations of the external reflectances in Yogyakarta.

\section{Conclusion}

In the dense humid tropical urban area under clear and overcast sky conditions, light shelf created the most uniform daylight distribution in wide rooms $(9 \mathrm{~m}$ to $12 \mathrm{~m})$ with North-facing windows in the Southern hemisphere and South-facing windows in the Northern hemisphere. The DA of the room with light shelf was better than the DA of the other fenestrations. Under overcast sky conditions with South-facing windows in the Southern hemisphere and North-facing windows in the Northern hemisphere, the DA of the rooms with light shelf was lower than that of without shading device. Variation in $h / w$ substantially modified the daylighting performance of light shelf application on low floor levels. The higher the $h / w$ (the denser the urban area), the stronger the effects on the $E_{\mathrm{i}}$ (distribution). Meanwhile, $l e / L$ had insignificant impacts on the daylighting and energy performance. Compared to the other fenestration types, the best energy performance (cooling load and energy for lighting) of light shelf applications were in highly dense urban area $(h / w=4$ and $l e / L=0.25)$ and on the first floor in any urban geometry.

High external wall and ground surface reflectance could improve the daylight level of a room equipped with light shelf in dense urban area. Whereas low external ground surface reflectance could increase the possibility in creating more uniform daylight distribution of a room equipped with light shelves in any aspect ratio of the urban context. Low external wall surface reflectance only improved the daylight distribution of a room equipped with light shelf in dense urban area. However, the external surface reflectance/albedo insignificantly influenced the building energy consumption. 


\section{ACKNOWLEDGEMENT}

Authors gratefully acknowledge Universitas Atma Jaya Yogyakarta for financially supporting this research entitled "The Effectiveness of Light Shelf in Equatorial Tropical Urban Context".

\section{REFERENCES}

[1] International Energy Agency. Energy Conservation in Building Community Systems (IEA-ECBCS). Annex 29/Solar Heating and Cooling Programmes Task 21, 2010.

[2] Wong N. H., Istiadji A. D. Effect of external shading devices on daylighting penetration in residential buildings. Lighting Research and Technology 2004:36(4):317-330. doi:10.1191/1365782804li126oa

[3] Binarti F. Lightshelf for improving indoor horizontal illuminance distribution. Teknik 2005:12(1):1-10.

[4] Lim Y. W., Heng C. Y. S. Dynamic Internal Light Shelf for Tropical Daylighting in High-rise Office Buildings. Building and Environment 2016:106:155-166. doi:10.1016/j.buildenv.2016.06.030

[5] Franco I. M. Efficacy of light shelves: passive, dynamic and automatic devices related to light and thermal behavior. Presented at Thermal Performance of Exterior Envelopes of Whole Buildings X, 2007

[6] Floyd D. B., Parker D. S. Daylighting: measuring the performance of light shelves and occupant controlled blinds on a dimmed lighting system. Presented at 11th Symposium on Improving Building Systems in Hot and Humid Climates, Fort Worth, USA, 1998.

[7] Ho M. C., Chiang C. M., Chou P. C., Chang K. F., Lee C. Y. Optimal sun-shading design for enhanced daylight illumination of subtropical classrooms. Energy and Buildings 2008:40:1844-1855. doi:10.1016/j.enbuild.2008.04.012

[8] Aboushi B. K. The Effect of Adaptive Shading and the Selective Reflective Light Shelves on Office Building Energy Efficiency and Daylight Performance in Hot Arid Regions. Master thesis, the University of Arizona, 2013.

[9] Binarti F. Energy-Efficient Window for Classroom in Warm Tropical Area. Presented at 11th IBPSA Conference, Glasgow, Scotland, 2009.

[10] Shafaghat A., Manteghi G., Keyvanfar A., Bin Lamit H., Saito K., Ossen D.H. Street Geometry Factors Influence Urban Microclimate in Tropical Coastal Cities: A Review. Environmental and Climate Technologies 2016:17:6175. doi:10.1515/rtuect-2016-0006

[11] Kesten D., Kereci A., Strzalka A., Eicker U. A method to quantify the energy performance in urban quarters. Indoor Air Quality, Ventilation 2012:18(1-2):100-111. doi: 10.1080/10789669.2011.583307

[12] Akbari H., Menon S., Rosenfeld A. Global cooling increasing world-wide urban albedo to offset $\mathrm{CO}$. Climate Change 2009:95(3-4). doi:10.1007/s10584-008-9515-9

[13] Tein B., Reynolds J. S., Grondzik W. T., Kwok A. G. Mechanical, Electrical and Equipment for Buildings. New York; John Wiley, 2009.

[14] Joarder A. R., Ahmed Z. N., Price A., Mourshed M. A Simulation assessment of the height of light shelves to enhance daylighting quality in tropical office buildings under overcast sky conditions in Dhaka, Bangladesh. Presented at 11th IBPSA Conference, Glasgow, Scotland, 2009.

[15] University of Illinois and Ernest Orlando Lawrence Berkelay National Laboratory. EnergyPlus Engineering Reference, 2013.

[16] Henninger R. H., Witte M. J. EnergyPlus testing with building thermal envelope and fabric load test from ANSI/ASHRAE Standard 140-2011. Washington DC: 2011.

[17] Manz H., Loutzenhiser P., Frank T., Strachan P. A., Bundi R., Maxwell G. Series of experiments for empirical validation of solar gain modeling in building energy simulation codes - experimental setup, test cell characterization, specifications and uncertainty analysis. Building and Environment 2004:41:1784-1797. doi: 10.1016/j.buildenv.2005.07.020

[18] Loutzenhiser P. G., Manz H., Carl S., Simmler H., Maxwell G. M. Empirical validations of solar gain models for a glazing unit with exterior and interior blind assemblies. Energy and Buildings 2008:40:330-340. doi:10.1016/j.enbuild.2007.02.034

[19] Hachem C., Athienitis A., Fazio P. Parametric investigation of geometric form effects on solar potential of housing units. Solar Energy 2011:85:1864-1877. doi:10.1016/j.solener.2011.04.027

[20] Goia F. Search for the optimal window-to-wall ratio in office buildings in different European climates and the implications on total energy saving potential. Solar Energy 2016:132:467-492. doi:10.1016/j.solener.2016.03.031

[21] Loutzenhiser P. G., Manz H., Felsmann C., Strachan P. A., Frank T., Maxwell G. M. Empirical validation of models to compute solar irradiance on inclined surfaces for building energy simulation. Solar Energy 2007:81:254-267. doi:10.1016/j.solener.2006.03.009

[22] Carroll W. L., Hitchcock R. J. DELight2 Daylighting Analysis in EnergyPlus Integration and Preliminary User Results. Presented at Ninth International IBPSA Conference, Montréal, Canada, 2005. 
[23] Huang Y., Niu J., Chung T. Comprehensive analysis on thermal and daylighting performance of glazing and shading designs on office building envelope in cooling-dominant climates. Applied Energy 2014:134:215-228. doi:10.1016/j.apenergy.2014.07.100

[24] McNeil A., Lee E. S. A validation of the Radiance threephase simulation method for modeling annual daylight performance of optically complex fenestration systems. Building Performance Simulation 2012:1-14. doi:10.1080/19401493.2012.671852

[25] Reinhart C. F, Andersen M. Development and validation of a Radiance model for a translucent panel. Energy and Buildings 2006:38(7):890-904. doi:10.1016/j.enbuild.2006.03.006

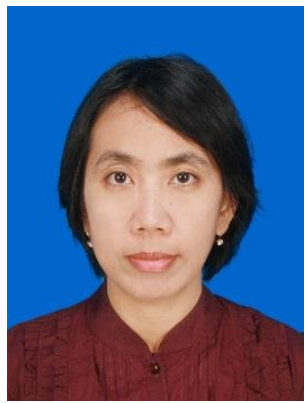

Floriberta Binarti received bachelor degree in architecture from Gadjah Mada University, Indonesia in 1993 and Master degree in solar architecture from Swiss Federal Institute of Technology Zurich (ETHZ), Switzerland in 2001.

Currently she is a full-time lecturer at Universitas Atma Jaya Yogyakarta, Indonesia (1994current). Following are recently published journal articles: (i) Binarti F. and Satwiko P. An east-facing anidolic daylighting system on a tropical urban house. Journal of Indoor and Built Environment 2016:25(4):691-702. doi:10.1177/1420326X15574787, (ii) Mediastika C. E. and Binarti F. Reducing Indoor Noise Levels Using People's Perception on Greenery. International Journal of Environmental and Climate Technologies 2013:11:19-27. doi:10.2478/rtuect-2013-0003, (iii) Binarti F., Istiadji A. D., Satwiko P. and Iswanto P. T. Interlayer and cavity contribution to creating high light-to-solar-gain-ratio glass block from waste glasses. International Journal of Sustainable Building Technology and Urban Development, 2013:4(1):82-88, doi:10.1080/2093761X.2012.759891. Her research interests are solar architecture, building performance simulation, and building energy.

Her current memberships are: (i) the Institute of Architect Indonesia, (ii) International Association of Building Physics, (iii) KES bronze member.

Contact details: Department of Architecture, Atma Jaya Yogyakarta University, Jalan Babarsari 44 Yogyakarta, Indonesia 55281. Phone: +62 274487711 Fax: +62 274 487748. Email: binarti@ mail.uajy.ac.id, flo.binarti@ gmail.com.

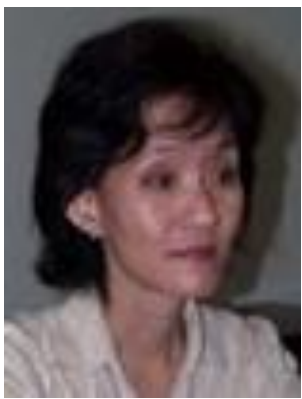

Sinta Dewi received bachelor degree in architecture from Gadjah Mada University, Indonesia in 1990 and Master degree in regional planning from Asian Institute of Technology, Thailand and Spring Dortmund, Germany in 1995.

She is a full-time lecturer at Universitas Atma Jaya Yogyakarta, Indonesia (1990-current) and works as free-lance architect and urban planner. Her research interests are sustainable architecture and green buildings.

She is a member of the Institute of Architect Indonesia and the Institute of Urban Planner Indonesia.

Contact details: Department of Architecture, Atma Jaya Yogyakarta University, Jalan Babarsari 44 Yogyakarta, Indonesia 55281. Phone: +62 274487711 Fax: +62 274487748. Email: sinta@mail.uajy.ac.id. 